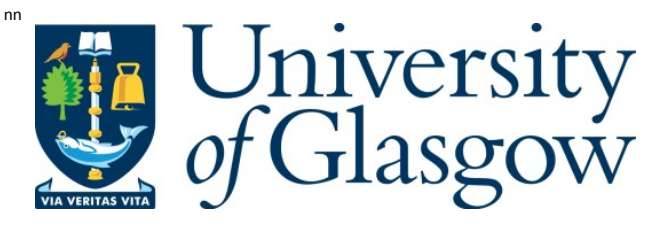

B anks, I. (2014) Digging in the dark: the underground war on the Western Front in WWI. Journal of Conflict A rchaeology, 9 (3). pp. 156-178.

Copyright $\odot 2014$ W. S. M aney \& Son Ltd

A copy can be downloaded for personal non-commercial research or study, without prior permission or charge

Content must not be changed in any way or reproduced in any format or medium without the formal permission of the copyright holder(s)

http://eprints.gla.ac.uk/102030/

Deposited on: 29 J anuary 2015

Enlighten - Research publications by members of the University of Glasgow http://eprints.gla.ac.uk 


\title{
Digging in the Dark: The Underground War on the Western Front in WWI
}

lain Banks

Centre for Battlefield Archaeology, University of Glasgow, Scotland, UK

\begin{abstract}
Throughout the First World War, with the trenches largely static, the combatants tried to break the deadlock by tunnelling under one another's trenches. The Tunnelling Companies of the British Royal Engineers were engaged in a bitter struggle against German Pioneers that left both sides with heavy casualties. A project to determine the location of one particular act of heroism in that underground war has resulted in the erection of a monument to the Tunnellers at Givenchy-lès-la-Bassée in northern France.
\end{abstract}

Keywords: Tunnelling Companies; Royal Engineers; William Hackett; Tunnellers' Memorial; mine warfare

\section{Introduction}

The war that raged from 1914 to 1918 is characterised in the popular imagination in terms of trenches, mud and shellfire. The image of young men clambering out of the trenches and running forward into devastating machine gun fire has been imprinted on the collective memory of the war by the fact that this was effectively the first conflict to be filmed. Grainy black and white images of figures stumbling across the mud and broken ground to an uncertain end are well-known, particularly with the centenary of the outbreak of war. This is only a partial representation of the Great War, and there were other dimensions to the battlefield. The trenches took men below the surface of the ground, to gain protection from enemy fire; dugouts provided sleeping quarters for men in the frontline. As artillery shells became more destructive, dugouts were dug deeper and deeper, many becoming larger and more intricate as they did so. However, this was still only part of the full story of the subterranean front. Tunnels were used to mount attacks against enemy trenches, by bringing men underneath no-man's-land to emerge just in front of the target; by packing the end of the tunnel with tons of explosives and creating an underground mine; or by housing a Livens Large Gallery Flame Projector (see Banks \& Pollard, this volume). Over recent years, there has been a greater amount of research into the underground war, largely led by the work of the historian Peter Barton, some of which has come to public notice as the result of TV documentaries. 


\section{Fighting Underground}

Precedents

There was nothing new about the use of tunnelling to attack enemy positions. This was a regular feature of siege warfare throughout the Medieval period, where the intent was to undermine and weaken the walls of towns and castles. As gunpowder appeared, it became a potent weapon to use against fixed defences; mines were excavated under walls, with the chamber being detonated and bringing the wall crashing down. This technique was used in the English Civil War on several occasions, such as at the siege of York; on 17 June, 1644, Parliamentarian troops were able to force their way into the Royalist defences through a hole created by the explosion of a mine below the tower on the abbey wall of St Mary's (RCHME, 1975: 18-19). Although the Parliamentarian assault was eventually beaten back, the success of the method was clear. In a later conflict, the Unionist forces successfully breached the defences of Petersburg, Virginia on July 30, 1864 by the use of a mine dug underneath the Confederate defences.

In the summer of 1864, the Union advance on Richmond was held up at Petersburg by entrenched Confederate troops, with the siege lasting for nine months. The similarities to the Western Front are striking (James, 1938: 7); the Union troops dug in and there was a stalemate. Just as happened fifty years later on the Western Front, attempts to break the deadlock led to a strategy of tunnelling under no man's land to place explosives beneath the enemy's trenches. In 1864, the mining effort was led by a former mining engineer, Lt-Col Henry Pleasants of the $48^{\text {th }}$ Pennsylvania Volunteers. Pleasants was an experienced civil and mining engineer, very capable of such an undertaking, and he had the advantage that most of the men under his command were also former Pennsylvania miners. Given the go ahead by General Burnside, the Union miners tunnelled around $156 \mathrm{~m}$ to a point below the Confederate trenches on 23 July 1864. They had encountered quicksand and a layer of marl that was described as being like putty, and had needed to shore the tunnel along its full length. Just as in the events of fifty years later, the Confederates became concerned about the prospect of a mine being dug and sank counter-mines to listen for mining activity. The Union miners, being fully aware of Confederate activities because of accounts from deserters, knew what they were hearing, while the Confederate miners were not sure where the mining noises were coming from (James, 1938: 13). On 30 July at $4: 45 \mathrm{am}, 8,000 \mathrm{lbs}(3,629 \mathrm{~kg})$ was detonated beneath the Confederate trenches. The effect was devastating on the Confederate troops, with four companies of the $18^{\text {th }}$ South Carolina Infantry 'shattered' by the explosion (James, 1938: 19). The Union forces failed to capitalise on the effects, however, waiting too long to attack and then going into the mine crater to shelter from Confederate fire. In the crater, they were a sitting target for the Confederate mortars, and were unable to repulse the Confederate infantry counter-attacks; Union losses were around 4,000, while the Confederates lost around 1,500. While the infantry attack was a failure, the mining attack succeeded dramatically and could easily have provided a breakthrough for the Union forces.

The use of mining as a military tactic went out of favour in Europe, however. There were a number of sieges of military fortifications during the Franco-Prussian War of 1870-71, but the lesson of that war appeared to be that large-calibre artillery would always be able to reduce such strongpoints; military theorists began to think more of mobile warfare where fortifications and defences would be obsolete (Jones, 2010: 18-19). The Anglo-Boer Wars of 1880-81 and 1899-1902 gave notice of the devastating cost of assaulting entrenched positions over open ground, but the lesson was ignored by 
European military strategists. While the Boer trenches were very costly to assault, they were defended positions in an otherwise open landscape; many of the military strategists commenting on the wars took more notice of the mobility of the Boer commandoes than the effectiveness of the trenches. As strange as this might seem, given the disparity in casualties suffered by the British against the Boers, there were reasons for the lack of attention paid to the use of successful use of trenches by the Boers. While the Boers used their trenches very effectively, to the extent that British soldiers complained that they were unable to see the men who were killing them, the British did not dig in as a response. Instead, they attacked Boer trenches over open ground, frequently having to withdraw after heavy casualties. There was also the example of Spion Kop, where entenched British troops were slaughtered by Boers who had the advantage of higher ground. Finally, trenches were used very little after the first year of the Second Boer War, specifically after the Battle of Bergendal, 21-27 August 1900. This was the last battle of the conventional phase of the Second Boer War and ended in a British victory. From that point on, the Boers fought as a guerilla force and had no need for trenches. Their tactics of raiding through highly mobile commando units added to the impression that the key factor of the war was mobility. The result was that the war was largely ignored by military theorists as a set of circumstances that would never arise in Europe (Anon, 1910: 365).

Despite this, there was a revival of interest in mining in some quarters following the Russo-Japanese War of 1904-05. This war was very influential in shaping military thinking throughout Europe, an influence that was to determine the pattern of the First World War. Two distinct elements were the subject of considerable discussion amongst military theorists, based on the nature of terrestrial warfare during this war. With land-based fighting largely based around Japanese sieges of Russian defensive positions, the fighting took two forms. The most obvious, and the one that attracted most attention from European onlookers, was the Japanese human wave assaults on Russian positions. The Japanese were able to overwhelm the Russian defences by sheer weight of numbers, where thousands of men were thrown forward, led by the ketshitai who had been told not to expect to return alive. The lesson taken from this by the military theorists of Europe was not that assaulting defended positions resulted in horrendous casualty levels, but that any position could be taken with sufficient numbers of attackers who continued the assault in the face of whatever the defenders could throw at them (Travers, 1979: 273). There were others who warned of the cost of such attacks, men such as Jean de Bloch who estimated that a numerical superiority of at least 8:1 was required to overwhelm a defended position (Bloch, 1903: xxvii), or Major Baden Baden-Powell (younger brother of Robert Baden-Powell). This younger member of the Baden-Powell family revealed a great deal of insight in his analysis of warfare following the Second Boer War (where he participated in the Relief of Mafeking in May 1900). In his analysis, he stated his belief that machine guns would make certain parts of the battlefield entirely impassable and argued against the use of daylight attacks (Baden-Powell, 1903). He placed a great deal of emphasis on the importance of defensive fortifications. However, he and Jean de Bloch were voices in the wilderness, and most theorists agreed with General Sir lan Hamilton. He had been with the Japanese army in Manchuria in 1904-5 as military attaché, seeing the Japanese assaults at first hand. He believed that what was required was a higher quality of soldier with strong martial spirit on the one hand, and the use of cover such as smoke, darkness or fog on the other (Travers, 1979: 272). He, and other European attachés present during the Russo-Japanese War, saw the effectiveness of the Japanese siege howitzers that wreaked havoc on Russian defences and believed that modern artillery would make fortresses impossible to hold against a determined assault. 
However, the other aspect of the Russo-Japanese War that had an influence was the use of mining by the Japanese to attack Russian positions. The Japanese tunneled under Russian positions and blasted holes in the defences; in particular, the forts that formed an important part of the defences of Port Arthur. On 18 December 1904, Fort Chikuan was damaged by a 1,800 kg mine and was taken the same night by Japanese assault. On 28 December, Fort Erhlung was largely destroyed by a large mine that killed a large part of the 500-strong garrison ( $26^{\text {th }}$ Siberian Rifles), who had been on parade at the time of the explosion. However, the survivors were able to hold out in the ruins of the fort for a further seventeen hours before being finally overwhelmed. Finally, on 31 December, a series of mines under the fort at Sungssu destroyed the fort magazine and with it most of the fort. A few days later, the Russian commander decided to capitulate (James, 1905:225-29).

The effectiveness of the mining operation did not have as strong an effect on the course of later warfare as the human waves of the Japanese assaults. Publications on military tactics in the period up to 1914 were substantially about the need for developing stronger and more motivated soldiers who would be able to face the rigours of assaulting the enemy's positions in the way that the Japanese soldiers had. However, there was a minor revival in interest in mining operations although largely with the French and Germans. There was a series of siege exercises carried out by the German between 1908 and 1913 (Jones, 2010: 17), but these focused more on the siege element with the building and defending of fortresses. They did at least practice with machines for boring through the ground, and they also practiced counter-mining strategies that included listening posts and procedures for attacking enemy galleries. However, as Jones notes, the general feeling amongst the German officer class was that any future war would be highly mobile, with some even arguing that defensive fortifications would become a trap that would paralyse the defending army (op. cit.: 18).

The French had a long tradition of military mining operations dating back to the days of Vauban, but like the Germans, they were largely convinced that an army holding defended positions was a sitting-duck for artillery bombardment. Despite this, the French continued to train in mining, training their sappers to dig shafts and galleries to assault the enemy from below, and how to counter-mine to keep the enemy sappers at a distance. They continued to have sections on mining and gallery construction in military manuals in the years leading up to the outbreak of WWI. France was undoubtedly the best prepared for the Underground War that was to come, although again their focus was more on dealing with and defending fortresses than on dealing with trench systems. What they did have, though, was an engineering section that was capable of mounting underground assaults against defended enemy positions.

Britain was the least prepared for mining warfare in 1914. With most of the High Command veterans of the South African campaigns, they were wedded to the idea of mobile warfare and cavalry. They were also utterly convinced that the conditions of the Boer Wars were specific to southern Africa and would never be replicated in Europe; they were consequently little prepared to look to the Boer Wars for The Russo-Japanese War had affected British officers as much as it had German and French officers, and all of the attention was on the quality of the fighting man. Travers quoted a range of military writers in the first decade of the twentieth century, all of whom were convinced of the need for motivated soldiers fighting for King and Country, taking aggressive and decisive action against the enemy (Travers, 1979: 272-75). In the face of this determination to rely on pluck and fortitude, there was little appetite for dealing with siege warfare. The one part of the British Army that did pay 
attention was the School of Military Engineering at Chatham. The lesson that they took from the Russo-Japanese War was that the Japanese had lacked technical ability in mining and countermining, and that the British Army had neglected these issues far too long. The Director of Manoeuvres also noted ominously in his report that:

The importance of Siege Manoeuvres has of late years been recognised by more than one Continental Power (School of Military Engineering, 1907: 7).

In the staff ride that was the subject of this report, the Royal Engineers sank mines below two forts near Chatham that were no longer in use. A great deal was learnt in the course of this project about noise suppression, ways of deceiving the enemy about the location of galleries, the need to conceal spoil from the galleries to disguise the mining activity and the dangers of carbon monoxide build up as a result of the explosion. This latter problem was severe; carbon monoxide levels underground rose substantially after a mine blow, which was a problem if troops were following up with an assuault through the galleries (as at Petersburg in the American Civil War and at Fort Erhlung in the Russo-Japanese War). The Royal Engineers found that the gas was trapped in the debris of the explosion; because carbon monoxide is heavier than air, it sank into the spoil and rubble of the blast zone. As soon as anyone tried to clear the passage to allow troops to pass, the carbon monoxide was released and caused dizziness and nausea (Jones, 2010: 24). Had the blast opened to the surface, then the problem would have been obviated by the supply of oxygen from the surface.

The Chatham exercise and a later version in June 1913 at Lulworth were reasonably successful in addressing problems that would be encountered in the coming war. However, the lessons learned were not widely disseminated, and it was clear that the Royal Engineers did not have sufficient numbers of men who were trained and experienced in work underground. A trained miner was far superior, able to dig more quickly and more quietly than men who had at best two or three days training per year (Jones, 2010: 27). This problem was mirrored in the German and French armies, with none of the protagonists on the Western Front starting the war with a cadre of mining warriors.

\section{First World War}

Contrary to the expectations of military strategists on both sides, the Western Front quickly settled into an entrenched stalemate, with the first entrenching taking place in September 1914 at the First Battle of the Aisne. German troops, who had dug in following their retreat from the First Battle of the Marne, decimated British troops attacking across open ground. Lacking any cover, the order was given to dig in and the Race to the Sea began. Within a month, trenches snaked all the way to the Belgian coast at Nieuport, while to the east, the trenches were continued in 1915 down to the Swiss border. This deadlock, which was effectively to last until 1918, led to a range of attempts to break through the enemy lines. Poison gas was one attempt, while the flame projectors discussed in this issue (Banks \& Pollard, this issue) were another. The most effective attempts to break the deadlock, however, came from using the same strategy as employed by Henry Pleasants at Petersburg and the Japanese at Port Arthur. Tunnelling underneath enemy positions to detonate large mines was a devastating tactic, not least because an attack could come from nowhere. 
The French were the first to undertake military mining in October 1914. Initially focused on defensive measures such as the provision of underground bunkers (Jones, 2010: 29), the French then constructed a system of defensive counter-mining measures on the Argonne front, in case the Germans attempted any underground assaults. It is ironic that the first 'shots' of the Underground War were in the form of defensive measures against a threat that did not yet exist. From that point, however, the French moved to offensive and began tunnelling towards German lines at DompierreBecquincourt in Picardie. This village, roughly $12 \mathrm{~km}$ to the west of Péronne, was the first incidence of mining and counter-mining on the Western Front, with both French and German mines and counter-mines being sunk. This proved to be the start of extensive underground operations between the French and Germans throughout the winter of 1914-15, with the Germans largely coming off better. Initially, there was little British involvement in this subterranean warfare, but this was to change from the end of 1914 onwards.

On 20 December 1914, German troops detonated 10 small (50 kg) blowpipe mines under the British frontline at Givenchy-lès-la-Bassée (fig. 1) at 9 am in the morning, killing many of the Sirhind Brigade who were holding the trench. The Germans were able to push at least $300 \mathrm{~m}$ into Allied territory before being stopped and then pushed back after four days of hard fighting. While the German attack had failed to make a decisive breakthrough, it had a substantial impact on British morale. The German report (quoted in Grieve \& Newman, 1936: 26-29) recounted that some of the Sirhind Brigade troops were found dead, still sitting in their dugouts. There had been no warning of the attack, no counter-mining measures in place; given the fact that the French and Germans had been attacking one another through mines since October, it suggests a degree of complacency on the part of the British strategists. The attack at Givenchy was followed by further German underground assaults that the R.E. Fortress Companies were unable to counter because of a lack of personnel and resources. According to one account, the situation was so severe that General French was considering having to withdraw some sectors of the frontline (Jones, 2010: 38). The British Army needed a response, which General Sir Henry Rawlinson (commanding the IV Corps) had suggested on 3 December 1914 should be a specialised mining battalion (Grieve \& Newman, 1936: 25); moves towards this had already begun in the background.

In November 1914, a former soldier, MP and civil engineer had written to the War Office proposing a team of specialised tunnellers to be sent under his command to France to undermine and blow up the enemy (Jones, 2010: 37). Major Sir John Norton-Griffiths was known to Lord Kitchener through his service in the Boer War and in Egypt, but had been concentrating on his civil engineering company since leaving the army. His initial approaches to the Army produced no results, but as the threat from the German underground assaults continued, he was called to see Lord Kitchener. He explained what his tunnellers could do, and how they would have an advantage over normal mining methods. His secret was to use claykickers, men who were used to working in the dense clays of the London Basin in particular. The technique was very different to the pick and shovel used by the French and Germans. Instead, the claykickers lay supine on a wooden frame and used a spade to cut blocks of clay from a vertical face, which were passed back to another man who would bag the clay and pass it back to a third man who would transport the clay along the tunnel on a trolley. They were able to work in confined spaces, and they worked very quietly. This was a critical advantage because noise was the biggest danger to miners underground. Both sides used listening posts to try and hear enemy miners at work: the position of the gallery could be located by triangulation from several listening posts, or by the use of geophones that could provide a bearing to the location of the 
noise. The claykickers had a lower of risk of being detected in the first place, with the additional benefit of being harder to locate. An additional advantage of the technique was that it was much more efficient. Rather than the standard galleries of a mine, which needed to be able to accommodate large numbers of miners and allow large quantities of minerals to be moved back to the surface, the galleries of a clay-kicker were used for service pipes and sewers (Grieve \& Newman, 1936: 33). This meant that the galleries were much smaller, which was more in keeping with military mining. As Grieve and Newman noted, the main purpose of a mining gallery was to get explosives under the enemy trenches (ibid.), so the clay-kickers used by Norton-Griffiths were used to working in the most efficient way for military purposes. Kitchener was impressed with the idea and gave Norton-Griffiths permission to start eight tunnelling companies within the Royal Engineers.

The first mining British operations were undertaken by sappers, serving soldiers in Brigade Mining Sections. These men were miners before the war, and were wither from the British Army Reserve or members of the Territorial Army. The initial assumption of the army was that the tunnelling companies would similarly be largely staffed by serving soldiers, but with a core of claykickers from Norton-Griffith's workforce. Indeed, Major Norton-Griffiths' first act in establishing the tunnelling companies was to close down contracts and move his men to the front. On 17 February, he made redundant a group of claykickers working in Manchester, and on 21 February they were in northern France on the frontline (Grieve \& Newman, 1936: 35). However, to staff the tunnelling companies, there were not enough miners in the British Army. Norton-Griffiths recruited civilians who, like his initial group of claykickers, were sent straight to the frontline without the weeks and months of training that military recruits normally received. In addition, Norton-Griffiths relaxed the requirements for entry into the tunnelling companies. He was happy to take anyone up to the age of 60 , which meant that there was a larger pool of very experienced men available to take the Underground War to the Germans.

This more open recruiting policy meant that the Tunnelling Companies were very different in tone to other formations of the British Army. There was far more of a civilian air about the tunnellers (or moles, as Norton-Griffiths always referred to them), but they did a tremendous job of taking control of the Underground War. It meant that the men were a very mixed group, and that they were far more experienced in their role than any other branch of the British Armed Forces. That experience allowed them to solve the problems caused by running sand long before the Germans, giving a critical advantage in 1915 and 1916. Running sand (also called Kemmel Sand; the Germans called it Schwimmsand) was a layer of sand and water under pressure between the sandy clay of the surface and the thick impermeable clays at greater depth. This sand and water mixture was prevalent across much of Flanders and it acted much as quicksand; in some situations, because of the pressure it was under, when the layer was breached it would 'fountain' up into the shaft, rapidly filling the shaft (Doyle, 2012: 79-80). To be able to tunnel effectively required being able to get below this layer, but this was a serious technical challenge, particularly for the Germans whose positions on higher ground tended to have deeper deposits of running sand to penetrate. The British solved the problem first; the initial success came with piling, where wooden boards cut with a chisel-shaped edge were driven into the wet ground to form a barrier to the running sand (Grieve \& Newman, 1936: 42). Once a box was created, the material inside the boards would be dug out without difficulty. This became problematic where the Kemmel Sands were deeper, but there was a more successful technique called tubbing. This was not used initially because of a shortage of material: the technique used steel collars that acted as a koffer dam, holding back the running sand as a shaft was sunk (fig. 2); the 
same technique had been used horizontally for the construction of the London Underground (op. cit., 41). These techniques, both used on similar soils in Britain, allowed the British tunnellers to get below the Kemmel Sand deposits at a time that the Germans considered it to be technically impossible. Once below the running sand, the British tunnellers were able to avoid German countermining and set mines with relative ease.

However, while they were relatively safe from counter-mining, it is undeniable that they worked in fearsome conditions, very different to the men in the trenches but potentially just as deadly. Working in the tunnels meant working in cramped conditions, generally by candlelight, always as quietly as possible to avoid attracting the attention of the enemy listening posts. There was constant danger: gas build ups, such as carbon monoxide, were an ever-present threat and the only gas monitors available were mice or canaries. Similarly, there was always a danger of falling levels of oxygen; like carbon monoxide, it was a silent killer whose only warning was a headache or drowsiness. Air pumps helped, but the threat was still there. There was always a risk of collapse; the tunnels were shored, but collapse could happen at any time, particularly during an artillery bombardment. The soils were not ideal for tunnelling. Much of the Western Front had running sand, a layer. Even the more stable strata had their issues. The chalk could be very friable, being largely frost-shattered (Doyle, 2014: 185), easily brought down by shells exploding on the surface. Clay seems very stable and will take a clean edge, but will shear along weak points in the structure of the soil, bringing large sheets of clay crashing down with little warning. There was also the risk of counter-mining: the enemy could attack with charges set through boring from their gallery into the opposing gallery, the blast killing some, with carbon monoxide released by the explosion killing others. Alternatively, the enemy could break through into the gallery as a raiding party, leading to hand to hand fighting in virtual darkness using clubs and knives more than firearms.

These horrendous conditions called for men of great courage as well as great skill, and the bravery of these men was recognised during the war, including Sapper William Hackett who was posthumously awarded the highest honour, the Victoria Cross. A Canadian tunneller, Captain Mitchell, was also awarded a V.C. but this was for protecting bridges over the Canal de l'Escault at Cambrai; Hackett's V.C. was the only one awarded for actions underground. However, despite this wartime recognition, until recently there was no memorial to the men fighting underground. There is a combined memorial and cemetery at Railway Wood $4 \mathrm{~km}$ to the east of Ypres that is to the memory of eight tunnellers who were killed in galleries below the cemetery, but this is specific to the fallen sappers and does not commemorate the other tunnellers and the tremendous feats of engineering that they achieved. The first commemoration of the tunnellers as a group was unveiled in 2010 at Givenchylès-la-Bassée, a memorial stone with images relevant to the tunnelling companies (see below).

\section{Sapper William Hackett, V.C.}

William Hackett was one of the civilian volunteers for the tunnelling companies. Aged 43 , he was a lot older than most of the soldiers in the trenches, but not for the tunnellers. Like very many of the tunnellers, he was a coal miner by trade and, although born in Nottingham, was living and working in Mexborough, Yorkshire (Ancestry.com, n.d.). He was a married man with children, but had volunteered initially for the infantry. He was too old to fight in the trenches, but the drive to recruit miners for the tunnelling companies meant that he was enlisted into the Royal Engineers, firstly 177 
Tunnelling Company and then 254 Tunnelling Company who were stationed at Givenchy-lès-laBassée (fig. 1). He arrived at Givenchy in November 1915 (Barton \& Banning, 2012). In the following Spring, he and his colleagues began a shaft to tunnel under No Man's Land which was given the name of Shaftesbury Avenue. By June, they were roughly $10 \mathrm{~m}$ below the surface and had tunnelled roughly a quarter of the distance to the German lines (ibid.). However, while the tunnellers were working their way through the difficult soils of an area that had been shelled and mined for over eighteen months, the Germans were also working underground. The British had not detected the German mining, and had no idea that the Germans had already reached their lines. At 2.50 am on 22 June 1916, the Germans detonated a large mine under the British frontline trench, which was held by the B Company of the $2^{\text {nd }}$ Battalion Royal Welch Fusiliers. Around two-thirds of the Welshmen were killed or wounded in the blast and in the ensuing German assault (Jones, 2010: 140). However, the survivors fought back and drove the Germans back out of the crater and re-established the frontline; because of their action, the mine crater was named the Red Dragon crater for the Welsh dragon.

Sapper Hackett was one of five tunnellers working in the Shaftesbury Avenue tunnel when the Germans blew their mine. The shockwave collapsed the tunnel and shaft, leaving the men trapped. Aware of the desperate position of the tunnellers, the mines rescue began a rescue mission. According to the diaries of Sapper John French, another member of 254 Tunnelling Company who arrived at Givenchy shortly after the German assault, the rescue team were able to communicate with the trapped men through the ventilation pipe, and they were able to keep a flow of oxygen to them. They were also able to pump water out, because the gallery was at risk of flooding from the water in the running sand layer above them (French, 2012). French's account, quoted on the Tunnellers' Memorial website courtesy of the Redruth Old Cornwall Society Museum, gives a flavour of the confusion and devastation caused by the blowing of the Red Dragon Mine. In addition to Hackett's party, French notes:

There are also two of our corporals missing. Lots of our Coy. had very narrow escapes from being buried $\&$ being captured. The entrances to some of the saps were blocked $\&$ the Germans missed in their hurry the men inside (French, 2012).

The following day, on 23 June, French recorded that the men were still alive but trapped. The rescue party was within 4-5 $\mathrm{m}$ of the tunnellers, but he notes that it was very difficult conditions: 'it is very slow work owing to so much broken timber and running muck' (ibid.). On 24 June, French recorded that during the night a hole was made through to the trapped party, and three of the men were able to crawl through the tiny space to safety. Unfortunately, one of the men, Sapper Thomas Collins, had been injured by a collapse of the gallery and was suffering several broken ribs. He was unable to get through the hole at the size it was, and his comrade William Hackett refused to leave him behind; food was passed to the two men while the rescue team prepared to try to enlarge the hole, but at that point, disaster struck:

The other fellow offered to stop in with him until they could make the hole bigger so they passed in some food to them. They had no sooner done that than there was another fall \& they were entombed again (ibid.).

It was no longer possible to reach Hackett and Collins through the existing hole, and for the next two days, the rescuers tried to reach them through a new gallery; the work was hampered by 'the water 
\& running muck' (ibid.) and by now French states that they were unable to get an answer from the men. On 27 June, five days after the Red Dragon mine was blown, the rescue attempt was abandoned; what was left of the shaft then collapsed entirely (Grieve \& Newman, 1936: 167). French's account is all the more haunting for the starkness with which he reports the end of the rescue:

Abandoned all hope of getting those two chaps out this morning \& stopped all rescue work for the condition of the shaft was so bad as to endanger the lives of the men working down there and they think that they are both dead. That chap Hackett died a hero for he could have come out with the others but would not leave his injured comrade' (French, 2012)

Hackett's choice to stay in the gallery was undoubtedly heroic, and his last words have been recorded as "I am a tunneller, I must look after the others first" (The London Gazette V.C. citation, quoted by Barton \& Banning, 2012) or "I am a Tunneller. I must look after my mate" (Grieve \& Newman, 1936: 166). Whether or not he did say this, with the nature of the broken ground, Hackett must have known that there was little chance of them being able to escape, as the V.C. citation noted. Hackett was posthumously awarded the Victoria Cross, the only one awarded for actions taken underground. It is possible that Hackett and Collins were killed in the collapse that sealed the hole on 24 June because French does not record any further contact with them after that point. There may have been further collapses of the gallery itself, but the last point at which they were known to be alive was the night of $23 / 24$ June.

\section{Red Dragon Survey}

On 19 June 2010, a memorial stone was unveiled at Givenchy-lès-la-Bassée combining a memorial to William Hackett with a commemoration of the efforts of the Tunnelling Companies as a whole. The monument was the initiative of Peter Barton, Jeremy Banning and Maggie Roxburgh and was paid for by donations (including one from the Centre for Battlefield Archaeology). The stone bears images evoking life underground: a canary and a mouse, together with moles to recall Norton Griffith's name for his men; the spades and tools of the tunnellers; geophones and so on (fig. 3). The monument stands near to the entrance to Shaftesbury Avenue Shaft. The design of the monument was based on Shaftesbury Avenue Shaft; the circular base is the diameter of the shaft, while the stone itself is the same size as the gallery in which Hackett and Collins were trapped. The stone has a T-shaped hole cut through it that allows visitors to look through towards the remains of the Red Dragon crater, and the location where Hackett and Collins remain. In order to do this, the location of Shaftesbury Avenue needed to be established as near as possible, and this was attempted through geophysical survey.

\section{Methodology}

The intention of the survey was to locate elements of the WW1 trench system, any indication of the entrance to Shaftesbury Avenue shaft and any indication of Red Dragon, the mine that caused the collapse. The crater was visible on the ground surface as a shallow dip in the surface of the field (fig $4 \mathrm{x}$ ), but it was hoped that the crater would be more distinct in the geophysical survey. It was 
decided that the best approach to surveying the area was to use resistivity because the First World War features were likely to respond well to the technique; magnetometry was considered as a possibility but the restrictions of time and the uncertainty of whether the magnetic survey would be successful in an area that was clearly full of metallic objects led to the decision to survey only with a resistivity meter. The survey design was a standard survey consisting of $20 \mathrm{~m}$ grid squares across the field beside the main road through the village. With time restrictions, it was decided that a fairly coarse-grained survey would have to suffice, so the interval was $1 \mathrm{~m}$ along traverses set $1 \mathrm{~m}$ apart. This meant that 400 readings were collected from each $20 \mathrm{~m}$ grid. This design allows a large area to be surveyed quite rapidly.

Resistivity is an electrical technique that measures the resistance encountered by an electrical current passed through the soil between two pairs of probes. It is adept at detecting negative features such as ditches and trenches because the soil structure of such features contains more air and water than undisturbed soil; on a normal prehistoric site, a great deal of detail can be recorded of subterranean features. However, it was recognised that the Western Front is not a normal set of circumstances because the soil in which the features lie has also been disturbed in a way that does not happen on a 'normal' site. French's account of conditions at Givenchy at the time of the Red Dragon blow describe very heavy artillery bombardments from the Germans, all of which will have had an impact on the soil structure in general. The other cause of concern was the nature of the soil. It is almost a charicature of the Western Front to talk of the sticky mud, but this was the result of the high clay content of the surface geology. The tunnellers were working below this in a thick layer of clay, but the surface soils also have a very high clay content. This is significant because clay does not produce much resistance for an electrical current. Readings on the resistivity meter are uniformly very low because clay bonds through weak electrical currents. It also tends to have a high water content (in which case there will be low resistance) or to be very dry, in which case there is difficulty getting a proper contact and readings are extremely high. The effect of these changes from moisture content can be seen in the resistivity results from Mametz (Banks \& Pollard, this volume), where the grids surveyed in damp conditions produced good results, while the grids surveyed after a period of dry weather have lost all of the detail of the earlier grids. These different issues meant that there was a risk that the survey would fail entirely. It was decided not to attempt magnetometry because of the amound of ordnance lying around on the surface of the fields around Givenchy. Much of this had the potential to cause strong magnetic responses that would mask other less magnetic anomalies, and it was felt that there was little reason to waste time on the magnetometer. However, later projects such as the Mametz survey (ibid.) demonstrated that the technique probably would have been successful.

The equipment used was a Geoscan RM15 resistivity meter, with the results downloaded and processed in Geoscan's Geoplot v3 software. This allowed the results to be filtered to remove background noise, largely consisting of the natural fluctuations in resistance that are present in all soils. The results were presented as greyscale plots that consisted of all the individual $20 \mathrm{~m}$ grids stitched together. In the event, 15 grids were surveyed, giving coverage of 6,000 $\mathrm{m}^{2}$, and covering the full extent of the crater itself. 
The readings in the survey were uniformly low, as had been expected given the high levels of clay in the soil at Givenchy. This means that the results have to be treated with due caution because the variations between the readings is very small, which means that it would be easy to misinterpret minor variations as major features. Equally, it is possible that major features would produce only very low anomalies. All geophysical survey that is not followed up by excavation has to come with a health warning because there are always several potential explanations for an anomaly; properly, the term 'anomaly' should always be used until it has been proven through excavation to be an archaeological feature. Without 'ground truthing', all that has been detected is an anomaly in the geophysical responses of the soil; excavation will determine whether the anomaly represents an archaeological feature, a geological feature or a random coincidence.

Looking at the plots of the field, the most obvious anomaly is a very large circular anomaly (A; fig. $5 b$ ) in the right hand, south eastern part of the plot. Although it is essentially circular, there is a break in the circuit on one side (north). There are indications of variation across the interior of the anomaly. The essential characteristics of the readings in the anomaly suggest a ring of compacted soil surrounding looser material in the interior. This is might be what could be expected of a mine crater. The explosion of the ammonal would throw the soil upwards, and it would then fall back, largely re-filling the crater. The edge of the crater would be compacted by the shockwave, which would be in the process of dissipating by the time that the soil was no longer flung upwards. The narrowness of the compaction would also be a result of the shallow penetration of the survey. The maximum effective detection of the $0.5 \mathrm{~m}$ frame used at Givenchy is around $1 \mathrm{~m}$ depth; accordingly, the interior of the mine crater would be beyond the detecting range of the instrument, resulting in the surface edges of the crater being detected, and the remainder of the base of the crater being missed. Instead, the survey picked up the fill of the crater, which was much looser and therefore provided a lower resistance. The dimensions of the anomaly seem to be as might be expected of Red Dragon, being roughly $45 \mathrm{~m}$ in diameter: the precise dimensions are difficult to determine as it is the physical effects of the blast that have been measured. It is hard to find an alternative interpretation of the results. The break in the circle represents a later mine blow; Red Dragon dates from June 1916, while this area was continuously in the front line being shelled and mined until the end of the war. It is likely that later action will have had an effect on the geophysical properties of the soil, particularly as this was the area of the front line that the 55th West Lancashire Division held against the German offensive of Spring 1918 (ibid.).

There are further anomalies within the circumference of the anomaly representing the mine crater. These may represent later uses of the crater, again adding to the palimpsest of the resistance patterning across the field. Excavation would clarify whether these do represent later elements of the trench system or whether they are artefacts of the overall pattern of resistance from the crater.

The plot is also affected by later landuse, and the stripping running across the plot is evidence of the return of the landscape to agriculture. There are two significant anomalies within the plot apart from the Red Dragon crater itself. There is a patch of high resistance on the edge of the crater (anomaly B, fig. 5b), which corresponds on the R.E. map of shafts, mines and trenches to the location of a shaft called Duck Bill No 2, and is later than the events surrounding the deaths of Hackett and Collins. The other, a lighter patch representing low resistance and further away from the crater (anomaly C) corresponds to the location of Shaftesbury Avenue on the map. The difference between the anomalies, one giving higher resistance and the other low resistance, needs some explanationit 
shold be noted that the readings generally were very low because of the high level of clay in the soil. The effect of this low dataset is that terms such as high and low are relative, and while anomaly B may be higher resistance than anomaly $\mathrm{C}$, in general terms it would count as a low resistance anomaly. It might suggest that there was more in the way of solid material at this location.

As ever with geophysical survey, a note of caution must be sounded over the interpretations. The anomalies represent variations in the readings recorded by the resistivity meter. They may be the variations in the strength of the resistivity in the soil caused by the actions of the First World War, but they could also be purely the result of surface soil conditions. In terms of the conditions of the survey, the results were uniformly low, with a very small range in the readings. It would be easy in the circumstances to see features that are not real. However, on the basis of the survey, the interpretations are the best fit for the readings and there is nothing else that can be suggested as representing the WWI features.

\section{Conclusion}

With all due caution noted, it was decided that the anomaly was in the right general location and the stone was oriented towards that spot. The visitor looking through the T-shaped cut in the stone will see the gentle dip of the crater and is looking at the best guess for the location of Shaftesbury Avenue shaft.

The results of the survey demonstrated the efficacy of resistivity survey for the Western Front, despite the difficulties of working on clay soils. It shows clearly that the landscapes of the First World War are capable of investigation through geophysical methods despite the amount of disturbance to the soil through the actions of war. There have been other projects that have similarly produced good results to illuminate aspects of the Great War, including Mametz (Banks \& Pollard, this volume), Plugstreet (Masters \& Stichelbaut, 2009) and Vampire dugout (Jacobs \& Pollard, 2009). While geophysical survey and aerial photography can reveal a great deal about the landscapes of the First World War, there is no real substitute for excavation, however. The results from Mametz are far more satisfying than the results from Givenchy because they are confirmed through excavation and are accompanied by material culture that provides a greater testimony of the experiences of the soldiers on the Western Front. The project at Givenchy-lès-la-Bassée was a small scale project and never intended to result in excavation; there is no good reason to disturb the remains of Sappers Hackett and Collins. However, it does raise the issue of whether archaeology adds anything to the understanding of the First World War. Much of this account has relied on documents, so there is a question of whether there is anything extra that can be added to that historical information. Undoubtedly, excavation would add a great deal. The fields of Givenchy are littered with the detritus of battle; shrapnel balls, rounds and cartridges lie everywhere. Fragments of bone can be found occasionally on the surface within the Red Dragon crater. The trenches provide the reality of the documentation, giving a concrete form to the abstractions of war diaries and individual accounts. We can see the duckboards, the pickets holding up the sandbags and find personal objects that relate to individuals who experienced the hell of the Western Front. Archaeology provides the visual and concrete that makes comprehensible the words of documents. With the project at Red Dragon, the geophysical survey only provides ghost images of what may lie beneath the surface of the soil. Yet in this case, this is enough. The plots of the resistivity survey show the dramatic result of the Red 
Dragon blow, cutting across the trench lines of the British frontline; there are indications of other shellholes in the plot. The purpose of the survey was to locate the position of Shaftesbury Avenue; within the parameters of geophysical survey on clay soils that were extensively churned by constant shellfire from 1914 to 1918, the location of Shaftesbury Avenue has been reasonably well identified, allowing the monument to Sapper Hackett, V.C. and the Tunnelling Companies to be erected facing towards the shaft. The anomaly generated by the Red Dragon mine is very clear, giving a stark message about the power of the explosions generated by the mining endeavours of both sides.

There is a nice balance to the monumentation at Givenchy-lès-la-Bassée. This small corner of the frontline was fought over throughout the war, and was significant for both the underground and the surface war. Reflecting this multi-dimensional battlescape, the Tunnelling Company monument (fig. 6) stands near to the monument to the $55^{\text {th }}$ West Lancashire Division (fig. 7). This latter monument was erected in memory of the men who held the line against the Kaiserschlacht, the German Spring Offensive that nearly broke through the Allied frontline, in 1918. Both the Tunnellers and the West Lancashires were instrumental in the outcome of the First World War in their different ways. There is a nice symmetry to the co-location of the monuments, one to the men who fought in mud and fire on the surface, the other to the men who fought in clay and darkness under the ground.

\section{Acknowledgements}

The Centre for Battlefield Archaeology would like to thank Peter Barton for instigating the survey project in 2005 and for his support throughout the project. We would like to acknowledge the support and assistance of DRAC during the project, and especially Alain Jacques, Director of the Arras Archaeological Service and a renowned expert in the archaeology of the Western Front. We would also like to pay tribute to Peter Barton, Jeremy Banning and Maggie Roxburgh for their vision, energy and effort in raising the monument to the Tunnelling Companies and Sapper Hackett, V.C. The monument stands on a bend in the D167 road (Rue des Bois Blancs) entering Givenchy-lès-laBassée; it should be a part of any tour to the Western Front.

\section{Bibliography}

Ancestry.com. n.d. UK, Victoria Cross Medals, 1857-2007. [online] [Accessed 29 July 2014]. Available at: < http://interactive.ancestry.co.uk/2483/40104 258646-

n0709/710?backurl=http\%3a\%2f\%2fsearch.ancestry.co.uk\%2fcgibin\%2fsse.dll\%3frank\%3d1\%26new\%3d1\%26MSAV\%3d1\%26msT\%3d1\%26gss\%3dangsc\%26gsfn\%3dWilliam\%26gsIn\%3dHackett\%26msddy\%3d1916\%26uidh\%3dte5\%26msddd\%3d2>

Anon. 1910. German Regulations for Field Fortifications and Conclusions Reached in Russia from the Battles in Defensive Positions in Manchuria (translated from the Militar Wochenblatt). Profession Memoir. Corps of Engineers, United States Army and Engineer Department at Large, 2(7). 
Baden-Powell, B. F. 1903. War in Practice: Some Tactical and Other Lessons of the Campaign in South Africa, 1899-1902. London: Isbister.

Barton, P. \& Banning, J. 2012. William Hackett, V.C. [online] [Accessed 30 July 2014]. Available at $<$ http://www.tunnellersmemorial.com/william-hackett-vc $>$.

De Bloch, J. 1903. The Future of War in its Technical, Economical and Political Relations. Trans. By R. C. Long. Boston: Ginn \& Co.

Doyle, P. 2012. Examples of the Influence of Groundwater on British Military Mining in Flanders, 1914-1917. In: E. P. Rose \& J. D. Mather, eds. Military Aspects of Hydrogeology. :London: Geological Society of London, pp 73-84.

Doyle, P. 2014. Geology and the War on the Western Front, 1914-1918. Geology Today, 30(5), 18391.

French, J. 2012. Eyewitness Account. [online] [Accessed 30 July 2014]. Available at: $<$ http://www.tunnellersmemorial.com/eye-witness-account $>$.

Grieve, W. G. \& Newman, B. 1936. Tunnellers. London: Herbert Jenkins.

Jacobs, K. \& Pollard, T. 2009. Vampir Dugout: Opgravingsverlag Archaeologische Prospectie. Unpublished report, Association for Battlefield Archaeology and Conservation (ABAC). Zonnebeke, Belgium.

James, D. H. 1905. The Siege of Port Arthur: Records of an Eye-Witness. London: T. Fisher Unwin

James, A. P. 1938. The Battle of the Crater. The Journal of the American Military History Foundation, 2(1), 3-25.

Jones, S. 2010. Underground Warfare, 1914-1918. Barnsley: Pen \& Sword.

Masters, P. \& Stichelbaut, B. 2009. From the Air to Beneath the Soil: Revealing and Mapping Great War Trenches at Ploegsteert (Comine-Warneton), Belgium. Archaeological Prospection, 16(4), 27985.

Royal Commission on the Historical Monuments of England (RCHME). 1975. An Inventory of the Historical Monuments in the City of York, Vol. 4: Outside the City Walls East of the Ouse. London: H.M.S.O.

School of Military Engineering. 1907. Report on a Preliminary Siege Staff Ride Held at Chatham, 6th to 10th May 1907 and Subsequent Siege Operations Held at Chatham, July and August 1907. Chatham: School of Military Engineering. 